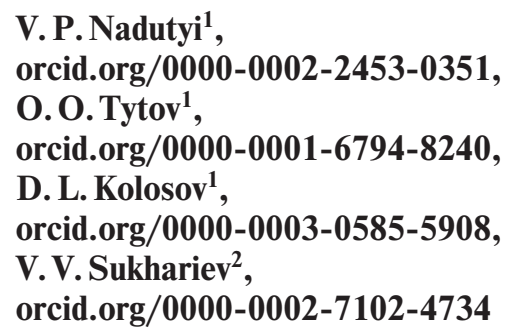

1 - Dnipro University of Technology, Dnipro, Ukraine, e-mail: alextitovalex77@gmail.com

2 - Institute of Geotechnical Mechanics named by N. Poljakov, Dnipro, Ukraine

\title{
INFLUENCE OF PARTICLE GEOMETRY ON THE EFFICIENCY OF OPERATION OF QUASISTATIC AND INERTIAL DISINTEGRATORS
}

Purpose. Research on interrelation of the efficiency of non-isometric particle destruction due to flexural deformation with the parameters of operational parts of new designs of roll and vibrational centrifugal disintegrators.

Methodology. A mathematical model of quasistatic flexural deformations of ellipsoid-shaped particles is developed for the case of their nip between the wave-profiled rolls of disintegrator, based on the classical problem of a beam bend with longitudinal compression. A mathematical model of inertial destruction of ellipsoid-shaped particles during free impact in a vibrational two-shaft centrifugal module is created based on combination of the beam bend problem, the contact deformations theory of Hertz and d'Alembert principle. The dependences of the key efficiency parameters of the mentioned disintegrators on the geometrical parameters of particles of processed mining rocks are obtained by the methods of generalization and dimensionless parametrization.

Findings. The analytical model of flexural tension realization in ellipsoid-shaped particles for disintegrator having the wave profile of rolls has allowed establishing that the increase in the length coefficient of ellipsoid-shaped particles from 1.5 to 4 units leads to the enhancement of breaking stresses from 1.7 to 12 times, compared to the case of smooth rolls. The analysis of the model of inertial disintegration of ellipsoid-shaped particles has revealed that the destruction of particles' narrow fractions in counter flows saves up to $20 \%$ of energy in comparison to the destruction by the rigid barrier. The particles of less than average size are destructed the most efficiently, during processing in counter flows and being in fractions of unequigranular structure. But the disintegration becomes more difficult as the relative size of particle rises.

Originality. Two mathematical models, which take into consideration the influence of flexural deformations of non-isometric particles modelled by ellipsoids on the level of breaking stresses for the disintegrators with wave profile of rolls, and also on the minimal speed of particles inertial flow for the vibrational two-shaft centrifugal module, are developed and analyzed.

Practical value. The obtained results allow determining the key parameters of operational parts for new designs of disintegrators. This forms the basis for development of techniques for calculation of operational parts of modern samples of crushing and grinding equipment.

Keywords: roll disintegrator, wave profile of roll, vibrational two-shaft centrifugal module, ellipsoid, flexural deformations

Introduction. It is fair to claim that at least two of three dimensions of non-isometric particles (minimal $a$, average $b$ and maximal $c$ ) are not equal to each other.

The analysis of crushed stone fraction of size from 5 to $20 \mathrm{~mm}$, being the closest to isometric, so called "cubical" shape, has shown that there is not a single piece of isometric shape among them all. Here the measurement accuracy was just $0.5 \mathrm{~mm}$. The higher the measurement accuracy would be, the less the probability was of detection of isometric pieces. It is also correct for other mining rocks.

At the same time, the efficient fracture stresses during influence of working surfaces on the rock pieces can differ up to several times even in case of processing cubical fractions, due to realization of flexural deformations. For example, the difference in crushers with the wave profile of rolls is up to 6 times, according to data of [1].

In this regard, the techniques for calculation of operational parts parameters, developed for most types of disintegrators and based on destruction of isometric (spherical or cubic) pieces under compressive or shear deformation, can no longer be considered as those having satisfactory accuracy.

Literature review. All existing disintegrators can be divided into two groups by the method of influence on the processed material:

1) those having quasi-static action and including jaw, cone and roll crushers [2];

2) those having inertial action and including machines of centrifugal and vibrational types [3].

Also, it should be noted that inertial effect may include both the peculiarity of machine mechanism being characteris-

(C) Nadutyi V. P., Tytov O. O., Kolosov D. L., Sukhariev V. V., 2020 tic mainly for vibrational disintegrators, for example, cone inertial crushers [4], and the way of particle destruction by acceleration in centrifugal field and abrupt stop when meeting the rigid barrier (hammer, rotary and centrifugal throwing machines) or the counter material flow (vibrational two-shaft centrifugal module [5]).

Destruction of pieces by quasistatic method requires at least one point of contact with each of two working surfaces, between which the material is being crushed [6]. The inertial forces are of hardly any significance here. The destruction of a cubic piece by monoaxial compression is mainly taken into consideration, with the rock strength coefficient determined by M.M. Protodiakonov technique [7]. But the calculated crushing force value can differ multiple times from the real value, because during industrial destruction, for example, in jaw crushers, real destruction conditions differ from laboratory conditions, when the force is applied strictly perpendicular to mutually parallel sides of cube.

It is known from the theory that destruction under shear or even compression load occurs eventually by extending of structural links inside a particle and their subsequent break [8]. So, the method for indirect determination of monoaxial tensile strength by compression of cylindrical rock samples with their generatrixes clamped between two parallel plates is more relevant [9], here the required value of tensile strength is calculated by formula, $\mathrm{Pa}$

$$
\sigma_{p}=0.64 \frac{P_{\max }}{h d},
$$

where $P_{\max }$ is destruction force, N; $h$ is the sample height, m; $d$ is the sample diameter, $\mathrm{m}$. 
It should be noted that the compressive strength of the rock and its tensile strength have good mutual correlation set by expression [7]

$$
\sigma_{p}=\psi \sigma_{c},
$$

where $\psi$ is the rock ductility factor.

The method for determination of rock ultimate compressive strength for the samples of irregular shape, given in book "Mining rock mechanics" by S. S. Grebionkin and N. N. Gavrish, is closer to practice, taking into consideration the fact that there are no real cubic and cylindrical rock pieces. The value is, $\mathrm{MPa}$

$$
\sigma_{c}=52.6 \frac{P_{a v}}{\sqrt[3]{V_{a v}^{2}}}
$$

where $P_{a v}$ is arithmetic average ultimate force of samples' compression between two parallel plates, $\mathrm{kN} ; V_{a v}$ is arithmetic average sample volume, $\mathrm{cm}^{3}$.

According to the method, it is necessary to test at least from 15 to 20 samples in terms of $(c / a) \leq 1.5$ restriction being not a problem. However, there is no conclusion how to test the strength of longer samples beyond the restriction.

The situation is more complicated for the case of inertial degradation of a piece by the rigid barrier or another piece when minimum one point of contact is needed [10]. The minimum speed of a piece, when after hitting the barrier it seems to have certain signs of disintegration, for example, splitting into two smaller pieces, is usually set in an experimental way, depending on the ultimate compression strength and the density of material [11]. It is established that the minimum impact speed rises together with decreasing the piece density and increasing the ultimate compression strength. Unfortunately, such a technique does not allow tracing the influence of the piece shape on its durability.

Unsolved aspects of the problem. The question remains not investigated how to distinguish the most significant parameters of the shape of processed mining rock particles, taking into consideration its deviation from isometric shape. It is necessary to estimate how the modeling views on disintegration working process will change if isometric particles are replaced by non-isometric. Also, there is a necessity to set the degree of influence of the implementable flexural deformations on the determined parameters of operational parts of disintegrators of quasistatic and inertial action.

Main part. Simulation of quasistatic deformation taking into consideration the particle shape parameters. As it has mentioned above, the shape of particles is conveniently characterized by values of minimal $a$, average $b$ and maximal $c$ dimensions by three mutually perpendicular directions.

During calculation of strength of particles destruction, they can be imagined in different shapes inscribed in set dimensions. Let us select such not complicated shapes, which can have three different dimension values and all central planes symmetry:

1) cuboid;

2) cuboid with rounded edges (pillow-shaped) [1];

3) ellipsoid;

4) hexagon in shape of two equal triangular pyramids, stacked together by bases in such a way that they mirror each other relative to the base plane.

The choice of any shape is generally conditional, although it effects the obtained results, because the real particles shape cannot be accurately described in terms of mathematics. However, the listed shapes, having equal corresponding dimensions, differ in calculated volume. We will characterize the relative value of the volume by the fill factor

$$
k_{f}=\frac{V}{a \cdot b \cdot c},
$$

where $V$ is volume of a particle.
The fill factor for the mentioned above determined shapes makes such values:

- $k_{f}=1$ for cuboid;

$-k_{f}=\pi / 6=0.524$ for ellipsoid;

- values for the pillow-shaped particles range from 0.524 to 1 , depending on the dimensions ratio;

$-k_{f}=0.167$ for the hexagon of two pyramids stacked together.

Real values of the fill factor are in a range between the values for hexagon and ellipsoid, closer to the last one, as to our own observations.

So, we will simulate the destructed particles by the closest to reality ellipsoids. Besides, the deviations from real particles in mass and area of cross sections will be taken into consideration by functions of the fill factor.

Let us consider the scheme of oblong particle bend in the crusher with wave profile of rolls [12], presented in Fig. 1.

The shown plane, drawn through three points, does not match the plane drawn through roll axes. Nevertheless, these planes can be aligned without making significant error in the calculation.

The most efficient position for the particle's destruction by bend is its clamp between rolls along the longest side. It leads to appearing of the maximum tensile stress at $B$ point under $Q$ cross forces, partially compensable by $N$ compression forces. Here, the following ratios are correct

$$
\begin{gathered}
Q=\frac{P}{2} ; \\
N=\frac{P}{2} \tan (\beta \cos \alpha)=\frac{P}{2} \tan \beta^{*},
\end{gathered}
$$

where $\beta$ is an angle of the generatrix of roll conic part to its axis inclination; $\alpha$ is the nip angle; $\beta^{*}$ is the efficient angle of generatrix inclination (practically, the value of $\cos \alpha$ strives for a unit, therefore we can count $\beta^{*}=\beta$ in some cases).

The real nip angle will depend not only on the geometry of rolls and a particle, but also on the friction conditions and the availability of moisture in the material [13]. However, this question is not discussed in detail in this work.

The tensile stress in $z$ direction for the most dangerous $B$ point is calculation from the expression

$$
\sigma_{p, B}=\frac{0.5 Q L-N l \cos \beta^{*}}{W_{y}}-\frac{N}{F_{x y}},
$$

where $L$ is the length of bending part, calculated by formula

$$
L=\frac{c^{2} \tan \beta^{*}}{\sqrt{a^{2}+c^{2} \tan ^{2} \beta^{*}}} ;
$$

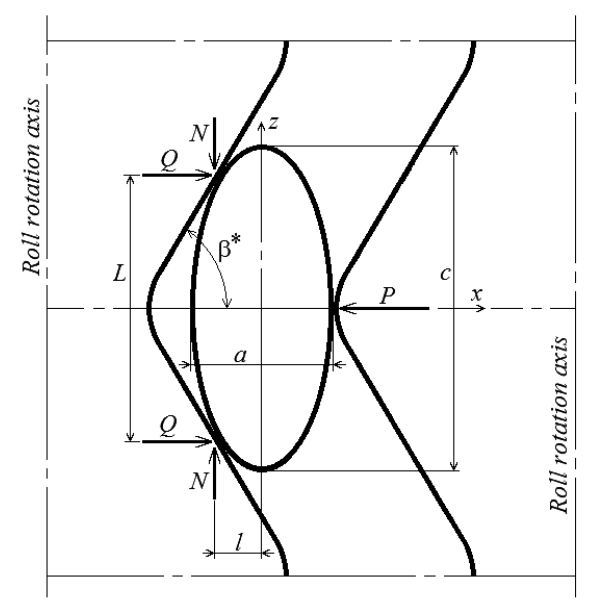

Fig. 1. The scheme of particle bend between wave rolls 
$l$ is the arm of force relative to $z$ axis

$$
l=\frac{a^{2}}{2 \sqrt{a^{2}+c^{2} \tan ^{2} \beta^{*}}},
$$

where $W_{y}$ is the axial section modulus of the piece in $x-y$ plane ( $y$ axis is perpendicular to the plane in Fig. 1, see above)

$$
W_{y}=\frac{\pi a^{2} b}{32} \frac{k_{f}}{0.524}
$$

$F_{x y}$ is the area of cross section of

$$
F_{x y}=\frac{\pi a b}{4}\left(\frac{k_{f}}{0.524}\right)^{2 / 3} .
$$

Here, two last values are corrected with due regard for the deviation of real particles' shape from ellipsoid shape through taking into consideration the influence of the particles' filling coefficient on the following ratio:

- for volumetric values

$$
\frac{k_{f}}{0.524}
$$

- for linear values

$$
\left(\frac{k_{f}}{0.524}\right)^{1 / 3}
$$

- for values of area

$$
\left(\frac{k_{f}}{0.524}\right)^{2 / 3}
$$

Generalization of (2-8) formulas gives the following expression of tensile stress in $\mathrm{z}$ direction for the most dangerous $B$ point

$$
\sigma_{p, B}=\frac{P}{a b}\left[\frac{1.33}{k_{f}} \cdot \frac{k_{c c}^{2} \tan \beta^{*}-\sin \beta^{*}}{\sqrt{k_{c a}^{2} \tan ^{2} \beta^{*}+1}}-\frac{0.414 \tan \beta^{*}}{k_{f}^{2 / 3}}\right],
$$

where $k_{c a}$ is the particle length factor

$$
k_{c a}=\frac{c}{a} .
$$

According to (1), the equivalent compression stress will be equal to the following value

$$
\sigma_{e, B}=\frac{\sigma_{p, B}}{\psi}
$$

or

$$
\sigma_{e, B}=\frac{P}{\psi a b}\left[\frac{1.33}{k_{f}} \cdot \frac{k_{c c}^{2} \tan \beta^{*}-\sin \beta^{*}}{\sqrt{k_{c a}^{2} \tan ^{2} \beta^{*}+1}}-\frac{0.414 \tan \beta^{*}}{k_{f}^{2 / 3}}\right] .
$$

Let us compare the destruction caused by bend to the case of the same particle destruction under shear loading in the crusher with smooth rolls, when its clamp is made at two points $A$ and $B$ (Fig. 1) with application of $P$ forces on both sides along $\mathrm{x}$ axis.

The measure of efficiency of material particle degradation in the crusher with waved profile of rolls compared to the smooth roll profile will be the coefficient of equivalent destruction stress increase, implemented in [1] technique. The expression for the coefficient will be written as

$$
k_{\sigma}=\frac{\sigma_{e, B}}{\sigma_{e 0, A B}},
$$

where $\sigma_{e 0, A B}$ is the equivalent shear stress along $\mathrm{AB}$ line being equal to the destruction stress for the piece of the same shape in the crusher with smooth profile of rolls

$$
\sigma_{e 0, A B}=\frac{2 P}{F_{x y} \sqrt{\psi}} .
$$

Let us transform the last expression, taking into consideration (8), to the following view

$$
\sigma_{e 0, A B}=\frac{1.65 P}{a b \cdot k_{f}^{2 / 3} \sqrt{\psi}},
$$

and then, regarding (9), it will go to the final formula

$$
k_{\sigma}=\frac{1}{\sqrt{\psi}}\left[\frac{0.806\left(k_{c a}^{2} \tan \beta^{*}-\sin \beta^{*}\right)}{k_{f}^{1 / 3} \sqrt{k_{c a}^{2} \tan ^{2} \beta^{*}+1}}-\frac{\tan \beta^{*}}{4}\right] .
$$

Let us compare the results obtained for ellipsoids with the results for pillow-shaped particles [1] featuring such dependences

$$
\begin{gathered}
\sigma_{e, B}=\frac{P k_{c a}^{2}}{\psi c^{2}}\left[\frac{2\left(k_{c a}-1\right)}{\frac{\pi}{4}+\frac{4}{3}\left(k_{b a}-1\right)}-\frac{\tan \beta^{*}}{2\left(\frac{\pi}{4}+k_{b a}-1\right)}\right] ; \\
\sigma_{e 0, A B}=\frac{2 P k_{c a}^{2}}{c^{2} \sqrt{\psi}\left(\frac{\pi}{4}+k_{b a}-1\right)},
\end{gathered}
$$

where $k_{b a}$ is the particle width factor determined by formula

$$
k_{b a}=\frac{b}{a} \text {. }
$$

Further, we will substitute all in expression (10) and go to the result

$$
k_{\sigma}=\frac{1}{\sqrt{\psi}}\left[\left(k_{c a}-1\right) \frac{k_{b a}-0.215}{1.33 k_{b a}-0.548}-\frac{\tan \beta^{*}}{4}\right] .
$$

The last expression matches, in general, the structure of equation (11). But, its principal difference is the availability of $k_{b a}$ width factor, having correlation with $k_{c a}$ factor depending on the mining rock type, instead of conditionally independent $k_{f}$ factor.

The calculation results for $\beta^{*}=30^{\circ}$ are shown in Fig. 2 .

As it goes from the given diagram, the stronger the influence of flexural destruction, which enhances the disintegration efficiency, is, the more the particle differs from isometric shape, the less the filling factor and the more fragile the mining rock is.

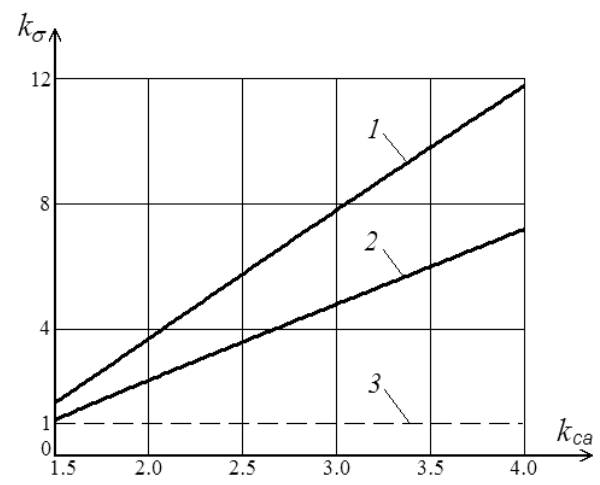

Fig. 2. Dependence of the coefficient of equivalent destruction stress increase on the relative length of particle for the crusher with wave profile of rolls:

1 - ellipsoid-shaped particles; 2 - pillow-shaped particles; 3 basic level (crusher with smooth rolls) 
For ellipsoid-shaped particles, $k_{c a}$ length factor makes the most influence. While it is increased by 2.7 times, the destruction stress rises by 7 times.

For pillow-shaped particles, the influence of $k_{c a}$ factor is 35-40 percent less than for ellipsoids. Besides, in this case, there is a dependence on a certain material type shown in correlation between $k_{c a}$ and $k_{b a}$, but, here, the difference does not exceed 4 percent.

In both cases, the destruction in the crusher with wave profile of rolls is more efficient than in the crusher with smooth rolls, for the whole $k_{c a}$ range researched.

Simulation of inertial disintegration. We will consider two variants of particle contacts: those with the rigid barrier and in counter flows.

The model of particle degradation under impact on the rigid barrier is presented in Fig. 3. The described position, when the smallest dimension is located along the impact direction, is the most efficient from the point of view energy consumption.

Suppose that the particle is disintegrated along the cross section including $A B$ line in $x-y$ plane similar to the case described in Fig. 1. The ultimate tensile stress is reached at $B$ point under bending of the particle by $Q_{i n}$ inertial forces applied at $C_{1}$ and $C_{2}$ points and equal to a half of $P$ maximum contact force.

Dangerous destruction stress should be calculated by a formula similar to (4)

$$
\begin{gathered}
\sigma_{p, B}=\frac{0.5 Q_{i n} L}{W_{y}} ; \\
L=\frac{3}{8} c .
\end{gathered}
$$

We will consider the destructed materials as rather fragile ones, having ultimate stress values matching the end of elastic deformation phase. Here, the maximum force of two elastic bodies' contact will be determined according to Hertz theory for the case of central impact. According to S. G. Orlov, accurate determination of the contact force between two ellipsoids in any possible position can be done only in terms of numerical methods, for example in work [14]. Besides, such complicity of calculations is not substantiated in case of known uncertainty of real particles shape. So, we will use Hertz theory for contact of two balls [15], taking into consideration the work "Elasticity theory" by S. P. Timoshenko and J. Gudier

$$
P=n \alpha^{1.5},
$$

where parameter $n$ for contact of two ellipsoid is approximately determined by formula

$$
n=\sqrt{\frac{3.56}{\left(\frac{1-v_{1}^{2}}{E_{1}}+\frac{1-v_{2}^{2}}{E_{2}}\right)^{2}\left(\frac{1}{R_{11}}+\frac{1}{R_{12}}+\frac{1}{R_{21}}+\frac{1}{R_{22}}\right)}},
$$

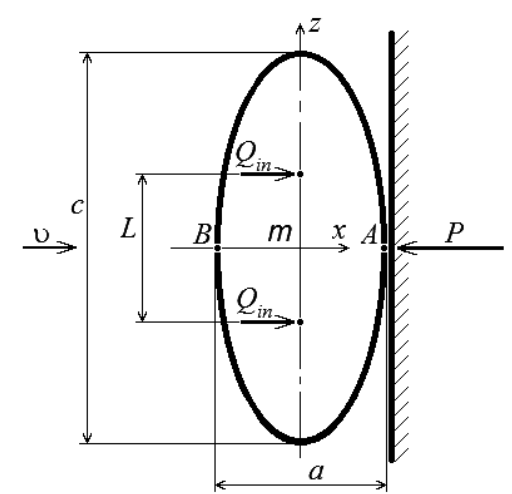

Fig. 3. Model of particle destruction under impact on the rigid barrier where $v_{1}$ and $v_{2}$ are Poisson's constants for the interacting bodies; $E_{1}$ and $E_{2}$ are corresponding elasticity modules; $R_{11}$ and $R_{12}$ are the main curvature radiuses at the contact point for the first body; $R_{21}$ and $R_{22}$ are the same values for the second body; $\alpha$ is contact deformation value, determined by formula

$$
\alpha=\left(1.25 \frac{v^{2} m_{1} m_{2}}{n\left(m_{1}+m_{2}\right)}\right)^{0.4},
$$

where $v$ is the initial relative speed of interacting bodies; $m_{1}$ and $m_{2}$ are masses of bodies.

Here, it is understood that the turn of bodies relative to each other is randomized for the set curvature radiuses, so the calculation is performed for the averaged variant.

The particle mass is low in the case of impact on the rigid barrier. It is illustrated by the expression

$$
m_{1}=\frac{\pi c^{3} \rho}{6 k_{b a} k_{c a}} \cdot \frac{k_{f}}{0.524} \ll m_{2},
$$

where $\rho$ is the ground material density, also the relative impact speed is equal to the particle speed $v$ before the impact. This calculation case is characteristic for hammer, rotary and centrifugal throwing crushers.

Here, the maximum contact deformation, taking into consideration expressions (15-17), will have the view

$$
\alpha_{1}=0.756 c\left[\rho v^{2}\left(\frac{1-v_{1}^{2}}{E_{1}}+\frac{1-v_{2}^{2}}{E_{2}}\right) \frac{k_{f}}{k_{c a}^{2}} \sqrt{\frac{k_{b a}^{2}+k_{c a}^{2}}{k_{c a}}}\right]^{0.4} .
$$

Expression for the maximum inertial force during the particle impact on the rigid barrier is determined by substituting the last result in equation (14)

$$
Q_{i n, 1}=0.62 \frac{\left(\rho v^{2}\right)^{0.6} c^{2}}{\left(\frac{1-v_{1}^{2}}{E_{1}}+\frac{1-v_{2}^{2}}{E_{2}}\right)^{0.4}}\left[\frac{k_{f}^{0.6} k_{b a}}{k_{c a}\left(k_{b a}^{2}+k_{c a}^{2}\right)^{0.2}}\right]^{0.4} .
$$

Next, generalization of equations $(10,12,13)$ and (18) leads to expression of the needed minimal flow speed enough for destruction of the particle into two parts during impact on the rigid barrier

$$
\mathrm{v}_{1}=\xi \frac{\lambda}{\sqrt{\rho}}\left(\psi \sigma_{c}\right)^{5 / 6}\left(\frac{1-v_{r}^{2}}{E_{r}}+\frac{1-v_{p}^{2}}{E_{p}}\right)^{1 / 3},
$$

where $\xi$ is the coefficient regarding the deviation of real impact conditions from simulated ones; $\lambda$ is generalized parameter being responsible for the particle shape and the side undergoing the impact

$$
\lambda=1.49 \frac{k_{f}^{1 / 3}\left(k_{b a}^{2}+k_{c a}^{2}\right)^{1 / 6}}{k_{c a}^{5 / 3}}
$$

where $v_{r}$ and $v_{p}$ are Poisson's constants for the mining rock and the plate, correspondingly; $E_{r}$ and $E_{p}$ are their linear elasticity modules.

Here, the relationship between ultimate limits of compression and tension is set by equation (1).

The dependence, corresponding to equation (19), is shown in Fig. 4 , taking into consideration the correlation between $k_{c a}$ and $k_{b a}$ parameters for basalt, granite and limestone in size range from 5 to $20 \mathrm{~mm}$.

It can be stated based on analysis of the last diagram, that the more the particle deviates from isometric shape, the less the necessary parameter of intensity is, i.e. disintegration can be performed at a lower speed of flow $v_{1}$. 


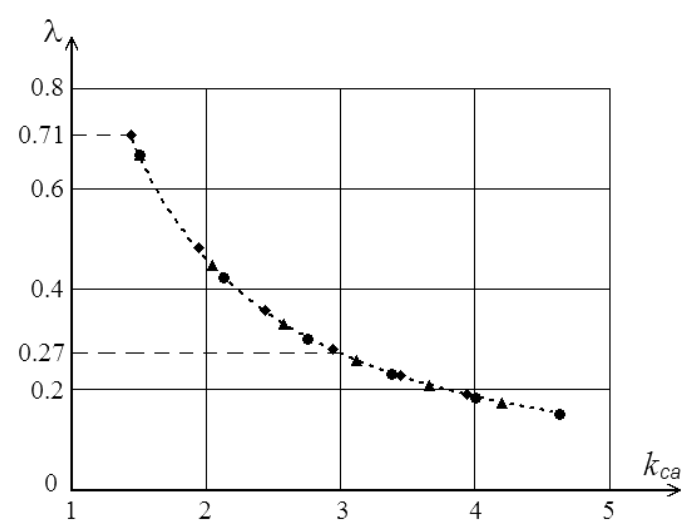

Fig. 4. Dependence of the generalized shape parameter on the particle relative length: triangles are for basalt; rhombuses are for limestone; circles are for granite

In particular, the parameter $\lambda$ for lamellar particles decreases from the maximum value 0.71 to the value 0.27 and less, so, more than by 2.5 times.

The speed of interaction doubles during impact of particles from counter flows (Fig. 5).

Every flow moves at speed value $v$, that is characteristic for disintegration in vibrational two-shaft centrifugal module [5]. Here, the masses of particles are set by the following expressions

$$
\begin{aligned}
& m_{1}=\frac{\pi c_{1}^{3} \rho}{6 k_{b a} k_{c a}} \cdot \frac{k_{f}}{0.524} ; \\
& m_{2}=\frac{\pi c_{2}^{3} \rho}{6 k_{b a} k_{c a}} \cdot \frac{k_{f}}{0.524} .
\end{aligned}
$$

Such formulas have been developed for the case of central impact of two particles, meeting the requirements similar to the ones described above:

- the maximum contact deformation

$$
\begin{gathered}
\alpha_{2}=0.756 c_{1}\left[\frac{\sqrt{1+\frac{c_{1}}{c_{2}}}}{1+\left(\frac{c_{1}}{c_{2}}\right)^{3}}\right]^{0.4} \times \\
\times\left[4 \rho v^{2}\left(\frac{1-v_{1}^{2}}{E_{1}}+\frac{1-v_{2}^{2}}{E_{2}}\right) \frac{k_{f}}{k_{c a}^{2}} \sqrt{\frac{k_{b a}^{2}+k_{c a}^{2}}{k_{c a}}}\right]^{0.4} ;
\end{gathered}
$$

- the maximum inertial force

$$
\begin{aligned}
Q_{i n, 2}=0.62 & \frac{\left(4 \rho v^{2}\right)^{0.6} c_{1}^{2}}{\left(\frac{1-v_{1}^{2}}{E_{1}}+\frac{1-v_{2}^{2}}{E_{2}}\right)^{0.4}}\left[\frac{k_{f}^{0.6} k_{b a}}{k_{c a}\left(k_{b a}^{2}+k_{c a}^{2}\right)^{0.2}}\right]^{0.4} \times \\
& \times \frac{1}{\left(1+\frac{c_{1}}{c_{2}}\right)^{0.2}\left[1+\left(\frac{c_{1}}{c_{2}}\right)^{3}\right]^{0.6}} ;
\end{aligned}
$$

- the required minimum absolute speed of particles, guaranteeing destruction of the first particle during interaction of counter flows

$$
\mathrm{v}_{2}=\frac{\xi}{2} \frac{\lambda}{\sqrt{\rho}}\left(\psi \sigma_{c}\right)^{5 / 6}\left(2 \frac{1-v_{r}^{2}}{E_{r}}\right)^{1 / 3}\left(1+\frac{c_{1}}{c_{2}}\right)^{1 / 6} \sqrt{1+\left(\frac{c_{1}}{c_{2}}\right)^{3}} .
$$

The relative efficiency of disintegration in current flows is determined as the ratio of two speed values

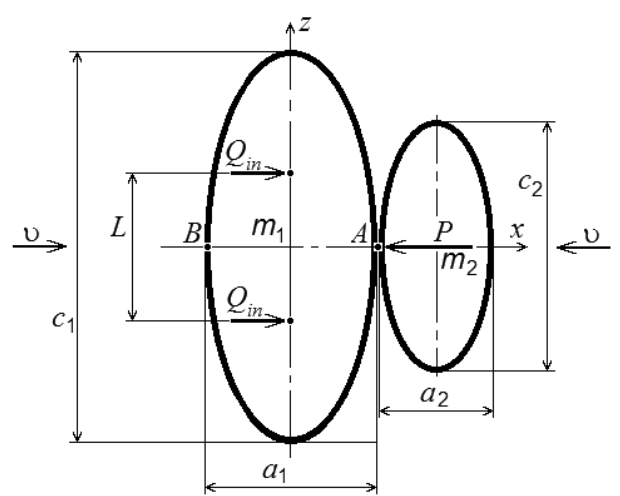

Fig. 5. Model of particle destruction in counter flows

$$
\frac{\mathrm{v}_{2}}{\mathrm{v}_{1}}=\frac{1}{2}\left[\frac{2}{1+\frac{1-v_{p}^{2}}{1-v_{r}^{2}} \frac{E_{r}}{E_{p}}}\right]^{1 / 3}\left(1+\frac{c_{1}}{c_{2}}\right)^{1 / 6} \sqrt{1+\left(\frac{c_{1}}{c_{2}}\right)^{3}} .
$$

The corresponding dependence is shown in Fig. 6.

The analysis of the diagram shows that the destruction in counter flows is the most efficient for the particles of $c_{1}$ size being much less than the average $c_{2}$ size. Here, for example for basalt, less relative speed values are requested, being approximately 0.57 units compared to the speed values of destruction on a massive barrier. Lower speed values of 0.9 units are needed for the particles of the average size with ratio equal to $\left(c_{1}: c_{2}\right)=(1: 1)$. The ratio of approximately $(1.13: 1)$ requires the value of relative speed equal to one unit. Disintegration of larger particles in counter flows (to the right of the dotted line) is less efficient, than impact on a massive barrier.

Besides, their characteristic curves almost match each other despite the essential differences in basalt and limestone properties.

So, the energy consumption during disintegration of narrow size classes of particles is reduced up to 20 percent compared to the case of disintegration on a rigid barrier.

Results. The analysis of flexural deformations of non-isometric shaped particles in newly developed roll and vibrational inertial disintegrators is fulfilled. The dependences of the increase in destruction stress level on the particle shape in disintegrators with wave-profiled rolls compared to smooth rolls are set. The relationship of the required speed of particles inertial flows in centrifugal disintegrators to the method of flows generation, the particles shape and their size ratio is revealed.

Conclusions. The analytical models of flexural stress realization in ellipsoid-shaped particles are developed for the dis-

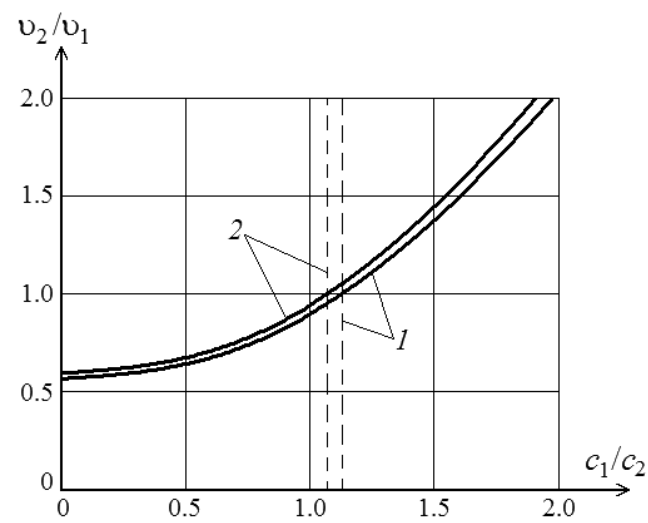

Fig. 6. Dependence of the minimal speed of counter flows on the particle size ratio:

1 is for basalt; 2 is for limestone 
integrator with wave-profiled rolls and the vibrational twoshaft centrifugal module.

It is shown that wave-profiled rolls increase the destruction stresses from 1.7 to 12 times in comparison with smooth rolls, while the length coefficient of ellipsoid differs from 1.5 to 4 units.

It is set for inertial disintegrators that the minimal speed of flows of lamellar particles can be decreased by 2.5 and more times compared to the case of isometric particles destruction. It is shown that the higher the efficiency of particle destruction in counter flows is, the less their size is relative to the average size of a processed fraction. It is established that the energy consumption of narrow fractions disintegration in counter flows is up to 20 percent less than in case of destruction on a massive plate.

The obtained results allow providing substantiated simulation of disintegration by quasistatic and inertial methods for mining rocks of any particle size distribution and particle shape.

\section{References.}

1. Tytov, O. O. (2019). Analysis of Mining Rocks Disintegration Conditions in Crushers Having the Wave Profile of Rolls. In: Modernization and Engineering Development of ResourceSaving Technologies in Mineral Mining and Processing, Multiauthored monograph, (pp. 366-380). Petrosani, Romania: UNIVERSITAS Publishing.

2. Bondarenko, A. O., \& Naumenko, R. P. (2019). Comprehensive solution of recycling waste from stone processing industry. Naukovyi Visnyk Natsionalnoho Hirnychoho Iniversytetu, (4), 96-101. https://doi.org/10.29202/nvngu/2019-4/14.

3. Sokur, M.I., Biletskii, V.S., Yehurnov, O.I., Vorobyov, O. M., Smyrnov, V. O., \& Bozhyk, D. P. (2017). Preparation of minerals for enrichment: monograph. Kremenchuk: Kremenchutskyi Natsionalnyi Universytet im. M. Ostrohradskoho, Akademiia Hyrnychykh Nauk Ukrainy: PP Shcherbatykh O.V.

4. Nazarenko, I., Mishchuk, Ye., \& Kuchynskyi, V. (2016). Evaluation and analysis of the main structural schemes of cone crushers. Hirnychi, budivelni, dorozhni ta melioratyvni mashyny, (88), 47-54.

5. Nadutyi, V.P., Loginova, A.A., \& Sukharev, V.V. (2019). Results of studies on the dependence of productivity of a vibrating twin-shaft centrifugal module on operating and design parameters. Vibration in engineering and technology, 3(94), 5-10.

6. Babets, D., Sdvyzhkova, O., Shashenko, O., Kravchenko, K., \& Cabana, E.C. (2019). Implementation of probabilistic approach to rock mass strength estimation while excavating through fault zones, Mining of Mineral Deposits, 13(4), 72-83. https://doi.org/10.33271/mining13.04.072.

7. Sdvyzhkova, O., Gapeiev, S., \& Tykhonenko, V. (2015). Stochastic model of rock mass strength in terms of random distance between joints. New Developments in Mining Engineering 2015: Theoretical and Practical Solutions of Mineral Resources Mining, 1, 299-300.

8. Davydenko, O. M., \& Ihnatov, A. O. (2019). Mechanics of effective destruction of rocks by cone-chain chisels. Porodorazrushaiushiy i metalloobrabatyvaiushchiy instrument, tekhnika ego izgotovleniia i primeneniia: Sb. nauch. tr., Kyiv, INM im. V. M. Bakulia NAN Ukrainy, (22), 148-157.

9. Hui, L., Freifei, Y., Yuguo, J., \& Hongmin, Z. (2017). Support controlling on shear type floor heave deformation in coal roadway. Boletin Technico, 55(3), 348-355.

10. Sdvyzhkova, O., Golovko, Yu., Dubytska, M., \& Klymenko, D. (2016). Studying a crack initiation in terms of elastic oscillations in stress strain rock mass. Mining of Mineral Deposits, 10, 72-77. https://doi.org/10.15407/mining10.02.072.

11. Hoshko, Z. (2016). Peculiarities of improvement of the electromagnetic vibrating crusher. Visnyk LNAU, Ahroinzhenerni doslidzhennia, 20, 140-149.
12. Nadutiy, V. P., \& Tytov O. O. (2019). UA Patent No. 132083. Dnipro: National Technical University "Dnipro Polytechnic".

13. Bondarenko, A.A. (2018). Modelling of interaction of inclined surfaces of a hydraulic classifier with a flow of solid particles. Naukovyi Visnyk Natsionalnoho Hirnychoho Iniversytetu, (4), 13-20. https://doi.org/10.29202/nvngu/2018-4/5.

14. Sachuk, Yu. V., \& Maksymuk, O.V. (2018). Computer modeling of elastic-plastic deformation in problems of contact interaction of canonical dies with a half-plane. Matematychne ta kompiuterne modeliuvannia. Seriia: Fisyko-matematychni nauky, (20), 126-134. http://dspace.nbuv.gov.ua/handle/123456789/162225.

15. Bobkov, S. P., \& Polishchiuk, I. V. (2016). Comparison of different approaches to determining the impact duration of solids during grinding. Vestnik IGEI, (5), 66-70.

\section{Вплив геометрії частинок на ефективність роботи квазістатичних і інерційних дезінтеграторів}

\section{В. П. Надутий ${ }^{1}$, О. О. Титов ${ }^{1}$, Д. Л. Колосов ${ }^{1}$, B. B. Сухарєв ${ }^{2}$}

1 - Національний технічний університет «Дніпровська політехніка», м. Дніпро, Україна, e-mail: alextitovalex77@ gmail.com

2 - Інститут геотехнічної механіки імені М. С. Полякова, м. Дніпро, Україна

Мета. Дослідження взаємозв'язку ефективності руйнування неізометричних частинок за рахунок деформацій вигину з параметрами робочих органів нових конструкцій валкових і вібраційних відцентрових дезінтеграторів.

Методика. На базі класичної задачі про вигин балки із прокольним стисканням розроблена математична модель квазістатичних деформацій вигину частинок еліпсоїдальної форми для випадку захоплення між валками дезінтегратора, що мають хвильовий профіль. На основі комбінацій задачі про вигин балки, теорії контактних деформацій Герца та принципу Даламбера створена математична модель інерційного руйнування еліпсоїдальних частинок під час вільного удару у вібраційному двовальному відцентровому модулі. Методами узагальнення й безрозмірної параметризації отримані залежності ключових параметрів ефективності роботи вказаних дезінтеграторів від геометричних параметрів частинок перероблюваних гірничих порід.

Результати. Аналітична модель реалізації напружень вигину в частинках еліпсоїдальної форми дозволила встановити, що при збільшенні коефіцієнта довжини еліпсоїдальних частинок з 1,5 до 4 одиниць руйнівні напруження підвищуються від 1,7 до 12 разів, порівняно 3 випадком гладких валків. Аналіз моделі інерційної дезінтеграції частинок еліпсоїдальної форми виявив, що руйнування вузьких фракцій у зустрічних потоках економить до $20 \%$ енергії порівняно з руйнуванням об жорстку перешкоду. Під час руйнування в зустрічних потоках фракцій полідисперсного складу найбільш ефективно руйнуються частинки, розмір яких менший за середній розмір фракцій, також зі зростанням відносної крупності частинок їх руйнування ускладнюється.

Наукова новизна. Створені та проаналізовані дві математичні моделі, за допомогою яких ураховано вплив деформацій вигину неізометричних частинок, що моделюються еліпсоїдами, на рівень руйнівних напружень для валкових дезінтеграторів із хвильовим профілем валків, а також на мінімальну швидкість інерційного потоку частинок для вібраційного двовального відцентрового модуля. 
Практична значимість. Отримані результати дозволяють визначити ключові параметри робочих органів для нових конструкцій дезінтеграторів. Це створює основу для розробки методик розрахунку робочих органів сучасних зразків дробарно-подрібнювального обладнання.

Ключові слова: валковий дезінтегратор, хвильовий профіль валка, вібраційний двовальний відцентровий модуль, еліпсоїд, деформації вигину

\section{Влияние геометрии частиц на эффективность работы квазистатических и инерционных дезинтеграторов}

\author{
В. П. Надутый ${ }^{1}$, А. А. Титов ${ }^{1}$, Д. Л. Колосов ${ }^{1}$, \\ B. В. Сухарев ${ }^{2}$
}

1 - Национальный технический университет «Днепровская политехника», г. Днепр, Украина, e-mail: alextitovalex77@gmail.com

2 - Институт геотехнической механики имени Н. С. Полякова, г. Днепр, Украина

Цель. Исследование взаимосвязи эффективности разрушения неизометрических частиц за счет изгибных деформаций с параметрами рабочих органов новых конструкций валковых и вибрационных центробежных дезинтеграторов.

Методика. На базе классической задачи об изгибе балки с продольным сжатием разработана математическая модель квазистатических изгибных деформаций частиц эллипсоидальной формы для случая захвата между валками дезинтегратора, имеющими волновой профиль. На основе комбинации задачи об изгибе балки, теории контактных деформаций Герца и принципа Даламбера создана математическая модель инерционного разрушения эллипсоидальных частиц при свободном ударе в вибрационном двухвальном центробежном модуле. Методами обобщения и безразмерной параметризации полу- чены зависимости ключевых параметров эффективности работы указанных дезинтеграторов от геометрических параметров частиц перерабатываемых горных пород.

Результаты. Аналитическая модель реализации изгибных напряжений в частицах эллипсоидальной формы для дезинтегратора с волновым профилем валков позволила установить, что при увеличении коэффициента длины эллипсоидальных частиц от 1,5 до 4 единиц разрушающие напряжения повышаются от 1,7 до 12 раз, по сравнению со случаем гладких валков. Анализ модели инерционной дезинтеграции частиц эллипсоидальной формы выявил, что разрушение узких фракций частиц во встречных потоках экономит до $20 \%$ энергии по сравнению с разрушением о жесткую преграду. При разрушении во встречных потоках фракций полидисперсного состава наиболее эффективно разрушаются частицы менее среднего размера фракций, а с ростом относительной крупности частиц их разрушение затрудняется.

Научная новизна. Созданы и проанализированы две математические модели, с помощью которых учтено влияние изгибных деформаций неизометрических частиц, моделируемых эллипсоидами, на уровень разрушающих напряжений для валковых дезинтеграторов с волновым профилем валков, а также на минимальную скорость инерционного потока частиц для вибрационного двухвального центробежного модуля.

Практическая значимость. Полученные результаты позволяют определить ключевые параметры рабочих органов для новых конструкций дезинтеграторов. Это создает основу для разработки методик расчета рабочих органов современных образцов дробильно-измельчительного оборудования.

Ключевые слова: валковый дезинтегратор, волновой профиль валка, вибрационный двухвальный центробежный модуль, эллипсоид, изгибные деформации

Recommended for publication by B.O. Bliuss, Doctor of Technical Sciences. The manuscript was submitted 23.06.20. 